\title{
Characteristic Comparison of an Intraoral Thin Film Containing Astaxanthin Nanoemulsion Using Sodium Alginate and Gelatin Polymers
}

\author{
Sodyum Aljinat ve Jelatin Polimerleri Kullanılmış Nanoemülsiyon \\ Astaksantin İçeren İntraoral İnce Filmin Karakteristiğinin Karşılaştırılması
}

\author{
(D) Lusi NURDIANTI1,2, (D) Taofik RUSDIANA ${ }^{1 *}$, (D) lyan SOPYAN¹, (i) Norisca Aliza PUTRIANA ${ }^{1}$, (D) Hanifa Rifdah AIMAN¹, (D) Tengku Ruhul FAJRIA \\ 1Padjadjaran University Bandung Faculty of Pharmacy, Department of Pharmaceutics and Pharmaceutical Technology, Jawa Barat, Indonesia \\ 2Bakti Tunas Husada Institute of Health Science, Department of Pharmacy, Tasikmalaya, Indonesia
}

\begin{abstract}
Objectives: The present study was conducted to compare the characteristics of a thin film containing an astaxanthin-loaded nanoemulsion (TFANE) using two kinds of natural polymers, namely sodium alginate and gelatin.

Materials and Methods: An astaxanthin nanoemulsion was prepared by using the self-nanoemulsifying method, followed by incorporation into a polymer matrix system by the solvent casting method to form TFANE. A characteristic comparison between the sodium alginate and gelatin matrix systems was carried out by comparing the physical and mechanical film properties. At the end of the study, in vitro dissolution tests were also assessed.

Results: An intraoral film with good physical and mechanical properties containing an astaxanthin-loaded nanoemulsion was developed successfully using a natural polymer matrix system. The film, made from a gelatin matrix system containing an astaxanthin nanoemulsion, was more flexible and harder than films made from a sodium alginate matrix system, where all of the films have ideal characteristics for intraoral delivery. The dissolution test results showed that, with both sodium alginate and gelatin, more than $90 \%$ of the drug was released at 15 minutes.
\end{abstract}

Conclusion: Gelatin as a natural polymer appears to be promising for the preparation of an intraoral thin film delivery system.

Key words: Astaxanthin, nanoemulsion, thin film, solvent casting method

Öz

Amaç: Bu çalışma, astaksantin yüklü nanoemülsiyon (TFANE) içeren ince filmin özelliklerini sodyum aljinat ve jelatin olmak üzere iki çeşit doğal polimer kullanılarak karșılaștırmak amacıyla yapılmıştır.

Gereç ve Yöntemler: Astaksantin nanoemülsiyon, kendiliğinden nanoemülsifikasyon yöntemi kullanılarak hazırlandı, ardından TFANE elde etmek için çözücü döküm yöntemi ile polimerler matris sistemine dahil edildi. Sodyum aljinat ve jelatin matris sistemlerinin karşılaştırması, fiziksel ve mekanik film özellikleri karşılaştırılarak gerçekleştirilmiştir. Çalışmanın sonunda in vitro çözünme testleri de değerlendirildi.

Bulgular: İyi fiziksel ve mekanik özelliklere sahip astaksantin yüklü nanoemülsiyon içeren intraoral film, doğal polimer matris sistemi kullanılarak başarıyla geliştirilmiștir. Tüm filmlerin intraoral ilaç taşınımı için ideal özelliklere sahip olduğu; astaksantin nanoemülsiyon içeren jelatin matris sisteminden yapılan filmin, sodyum aljinat matris sisteminden yapılan filmlerden daha esnek ve daha sert olduğu tespit edilmiştir. Çözünme testi sonuçları, hem sodyum aljinat hem de jelatinin 15 dakikada ilacın \%90'ından daha fazla salındığını gösterdi.

Sonuç: Doğal bir polimer olarak jelatin, intraoral ince film ilaç taşıyıcı sisteminin hazırlanması için umut verici görünmektedir.

Anahtar kelimeler: Astaksantin, nanoemülsiyon, ince film, çözücü döküm yöntemi 


\section{INTRODUCTION}

Astaxanthin is a lipophilic pigment with a reddish color, synthesized naturally by algae or plants. As a member of the xanthophyll group of compounds, which comprises oxygenated derivatives of carotenes, astaxanthin contains conjugated double bonds, hydroxyl groups, and ketone groups and possesses both lipophilic and hydrophilic properties. Its unique structure gives astaxanthin strong antioxidant power and superior biological activity to that of other antioxidants, owing to its ability to forms linkages with the cell membrane. ${ }^{1-3}$

In humans, the bioavailability of carotenoids is low and variable (10\%-50\% of a given dose), due to their low solubility in gastrointestinal tract juices, leading to poor absorption in the small intestine. ${ }^{3}$ Another factor that lowers the bioavailability of astaxanthin is its degradation in the gastrointestinal tract and the possibility of first-pass metabolism. A pharmacokinetic study by Choi et al. ${ }^{1}$ showed that the hepatic and gastrointestinal elimination extraction ratios of astaxanthin were 0.490 and 0.901 , respectively. The value of the elimination extraction ratio ranges between 0 and 1 , where a value close to 1 indicates that the drug is eliminated by the intended organ.

To overcome these drawbacks, an astaxanthin nanoemulsion was developed. A nanoemulsion preparation may offer an improvement in dissolution and absorption rates, while also improving the drug release profile., 4,5 Furthermore, to facilitate its use in patients; the astaxanthin nanoemulsion was incorporated into a polymer matrix system to create a thin film for intraoral use. This research was extended to develop a new dosage form to maximize the use of astaxanthin. In this research, astaxanthin was encapsulated in oil in an oil-in-water nanoemulsion system. This nanoemulsion was developed by the self-nanoemulsifying method. Then, two different natural polymers, sodium alginate and gelatin, were selected to obtain the best film matrix that was able to incorporate the astaxanthin nanoemulsion. Both physical and mechanical evaluations of thin film containing an astaxanthin-loaded nanoemulsion (TFANE) were performed, including $\mathrm{pH}$ and viscosity of filmforming mixtures, film thickness, film weight uniformity, film disintegration time, tensile strength, percent elongation, and film morphology.

\section{MATERIALS AND METHODS}

\section{Materials}

Astaxanthin (Astareal ${ }^{\circledR}$ L10) was purchased from Fuji Chemical Industries (Japan). Sunflower oil was purchased from Jan Dekker International (The Netherlands). Polyoxy-35-castor oil (Kolliphor ${ }^{\circledR}$ RH40) was purchased from BASF (Indonesia). Polyethylene glycol 400 (PEG 400) was purchased from Merck (Indonesia). Sodium alginate was purchased from Merck (Indonesia). Poly [butyl methacrylate, (2-dimethylaminoethyl) methacrylate, methyl methacrylate] 1:2:1 (Eudragit ${ }^{\circledR}$ EPO) was purchased from Evonik Industries (Thailand). Gelatin was purchased from Global Capsules Ltd (Bangladesh). All other chemicals used were of pharmaceutical grade.

\section{Preparation of the astaxanthin nanoemulsion}

The astaxanthin nanoemulsion was prepared by using the selfnanoemulsifying method with the optimized ratio of oil phase to surfactant to co-surfactant determined in a previous study. 6 Forty milligrams of astaxanthin was added to the 1-gram mixture of oil phase (sunflower oil), surfactant (Kolliphor ${ }^{\circledR} \mathrm{RH} 40$ ), and co-surfactant (PEG 400) in the ratio 1:8:1, respectively. This mixture was then mixed with a mixing speed of 100 rpm for 30 minutes using a magnetic stirrer (IKA ${ }^{\circledR}$ C-MAG HS7), followed by sonication for 1 hour $\left(K_{r i s b o w}{ }^{\circledR}\right)$. A nanoemulsion was formed by addition of deionized water with mild stirring.

\section{Optimization of thin film preparation}

In this study, sodium alginate and gelatin were used as thin film-forming polymers, with PEG 400 as a plasticizer. The experiment to optimize both the polymer and the plasticizer concentration that produced the best thin-layer preparation was designed by using Design-Expert ${ }^{\circledR}$ Version 12 Software with the Simple Lattice Design method. A thin film was formed by pouring the wet mixture (WME) into a petri dish with a flat, clean surface of diameter $10 \mathrm{~cm}$ and dried for 48 hours at ambient temperature $\left(30^{\circ} \mathrm{C} \pm 5^{\circ} \mathrm{C}\right)$. After drying, the film thickness and film disintegration time were evaluated. The experimental design results from the software are given in Table 1.

\section{Preparation of TFANE}

A quantity of $1.25 \mathrm{~g}$ of the astaxanthin nanoemulsion was dispersed slowly into a mixture of the optimized polymer matrix

\begin{tabular}{|c|c|c|c|c|}
\hline \multirow[b]{2}{*}{ Formula } & \multicolumn{4}{|l|}{ Components } \\
\hline & $\begin{array}{l}\text { Sodium } \\
\text { Alginate (g) }\end{array}$ & $\begin{array}{l}\text { Gelatin } \\
\text { (g) }\end{array}$ & $\begin{array}{l}\text { PEG } 400 \\
(\mathrm{~g})\end{array}$ & Deionized water \\
\hline $\mathrm{F} 1$ & 0.125 & - & 0.625 & \multirow{16}{*}{ Add up to $25 \mathrm{~mL}$} \\
\hline $\mathrm{F} 2$ & 0.281 & - & 0.500 & \\
\hline F3 & 0.438 & - & 0.375 & \\
\hline $\mathrm{F} 4$ & 0.594 & - & 0.250 & \\
\hline F5 & 0.750 & - & 0.125 & \\
\hline F6 & 0.438 & - & 0.375 & \\
\hline $\mathrm{F} 7$ & 0.125 & - & 0.625 & \\
\hline F8 & 0.750 & - & 0.125 & \\
\hline F9 & - & 0.25 & 0.250 & \\
\hline F10 & - & 0.25 & 0.250 & \\
\hline F11 & - & 1.00 & 0.156 & \\
\hline $\mathrm{F} 12$ & - & 0.75 & 0.188 & \\
\hline F13 & - & 1.25 & 0.125 & \\
\hline F14 & - & 0.75 & 0.188 & \\
\hline F15 & - & 1.25 & 0.125 & \\
\hline F16 & - & 0.50 & 0.219 & \\
\hline
\end{tabular}

PEG: Polyethylene glycol 
system and $0.01 \mathrm{~g}$ Eudragit ${ }^{\circledR}$ EPO (in $2.5 \mathrm{~mL}$ ethanol $96 \%$ ). The final mixing was performed by adding deionized water up to 25 $\mathrm{mL}$ and mixing with a magnetic stirrer (IKA ${ }^{\circledR} \mathrm{C}-\mathrm{MAG} H \mathrm{HS7}$ ) in 100 rpm for 1 hour. A thin film was formed by pouring this WME onto the flat, clean surface of a petri dish with a diameter of 10 $\mathrm{cm}$ and dried for 48 hours at ambient temperature $\left(30^{\circ} \mathrm{C} \pm 5^{\circ} \mathrm{C}\right)$. Then, the TFANE was cut into a $3 \times 3 \mathrm{~cm}$ square.

\section{Physical, chemical, and mechanical characterizations of TFANE}

\section{Visual observation and $\mathrm{pH}$ determination}

Visual observation included observation of the color, odor, and clarity of the WME. The $\mathrm{pH}$ of the WME was determined by using a calibrated $\mathrm{pH}$ meter (Mettler ${ }^{\circledR}$ Toledo).

\section{Film thickness and weight uniformity}

Film thickness was determined by using a micrometer (Mitutoyo ${ }^{\circledR}$ ) at three different locations on the film. Meanwhile, the weight uniformity of the thin film was determined by weighing six pieces of thin film (with a size of $3 \times 3 \mathrm{~cm}$ ) using an analytical balance (Mettler Toledo XS204). It is important to know these parameters because they are directly related to the accuracy of doses in the film. The thickness requirement for thin film dosage form must be in the range of 0.005 to $0.2 \mathrm{~mm}^{7}$

\section{Film disintegration time}

The film disintegration time was determined visually in a petri dish containing $10 \mathrm{~mL}$ of phosphate buffer, $\mathrm{pH} 6.8$ at $37^{\circ} \mathrm{C}$ with shaking every $10 \mathrm{~s}$. Disintegration time is the time at which the film begins to break or collapse. The disintegration time of a good thin film is less than $60 \mathrm{s.}^{7}$

\section{Tensile strength and percent elongation}

Mechanical stress tests of TFANE were performed by using a universal testing machine (Oriented UCT-5T). Dry film was cut into pieces of uniform size using a sharp-bladed cutting mold. Film (with area exposed to the stress of $25 \mathrm{~mm} \times 4 \mathrm{~mm}$ ) was sandwiched between two machine jaws. The load was given to the film gradually (at a speed of $30 \mathrm{~mm} /$ minute) and automatically until the film shredded. The test was carried out at $23^{\circ} \mathrm{C}$ and $50 \%$ relative humidity. Tensile strength is calculated by the applied load at rupture divided by the cross-sectional area of the film. Percent elongation is defined as a strain of the film. Strain is basically the deformation of the strip divided by the original dimension of the sample.

\section{Film morphology}

The film morphology of TFANE was examined by scanning electron microscopy (SEM). The sample was sized according to the specimen container, followed by smearing with silver paste at several points before the sample was placed. The sample was dried at $20^{\circ} \mathrm{C}$. The sample was fine coated as a voltage of $1.2 \mathrm{kV}$, current of 6-7.5 mA, and air pressure of 0.2 torrs for 4 minutes to obtain a sample with a thickness of approximately $400 \AA$.

\section{Assay of astaxanthin in TFANE}

The assay was carried out by dissolving the TFANE (with a size of $3 \times 3 \mathrm{~cm}$ ) in a volumetric flask containing $10 \mathrm{~mL}$ of phosphate buffer $\mathrm{pH} 6.8$ for 30 minutes. Then, the absorbance was measured by ultraviolet-visible spectrophotometry (Genesys ${ }^{\mathrm{TM}}$ $10 S$ ) at a maximum wavelength of $472 \mathrm{~nm}$. The astaxanthin concentration in the TFANE was calculated by estimating the astaxanthin content in the individual film. The limit of the assay is $85 \%-115 \% .^{8}$

\section{In vitro dissolution test}

In vitro dissolution tests were performed using a USP 41 apparatus 2, paddle apparatus. Nine hundred milliliters of phosphate buffer ( $\mathrm{pH}$ 6.8) was used and maintained at $37^{\circ} \mathrm{C}$ $\pm 5^{\circ} \mathrm{C}$, and the paddle was set at $50 \mathrm{rpm}$. A film sample of $9 \mathrm{~cm}^{2}$ $(3 \times 3 \mathrm{~cm})$ was cut and added to the medium. Five milliliters of samples were removed at predetermined time points at $1 ; 2 ; 3$; 4; 5; 10; 15; and 20 minutes, and the same amount was replaced with fresh buffer. The withdrawn samples were filtered and analyzed using a spectrophotometer at a wavelength of $472 \mathrm{~nm}$. The percentage release was calculated, and the relationship between time and percentage release was plotted.

Statistical analysis was not used in this research.

\section{RESULTS AND DISCUSSION}

\section{Preparation of the astaxanthin nanoemulsion}

Self-nanoemulsifying dosage forms are anhydrous homogenous liquid mixtures consisting of an oil, surfactant, drug, and co-surfactant, which spontaneously form an oilin-water nanoemulsion upon dilution with water under gentle stirring. ${ }^{4,5}$ Adding a surfactant and co-surfactant to such systems enhances drug dissolution and formulation dispersibility during dilution with the aqueous medium of GIT. During dilution with water, the active substance dissolves in the oil phase and/or surfactant, which forms a film between the oil and water phases. ${ }^{4}$ The appropriate type and ratio of the oil phase, surfactant, and co-surfactant are critical parameters in the formation of nanoemulsion. Based on our previous study, the best ratio between sunflower oil as the oil phase, Kolliphor ${ }^{\circledR}$ $\mathrm{RH} 40$ as the surfactant, and PEG 400 as the co-surfactant was $1: 8: 1$, respectively. ${ }^{6}$ Our results showed that the astaxanthin nanoemulsion had droplet sizes in the nano-range $(26-27 \mathrm{~nm})$ with a polydispersity index less than 0.5 (0.2-0.3) and a zeta potential value more than $(-20) \mathrm{mV}$.

\section{Optimization of thin film preparation}

In the preliminary study, prior to formulation of the astaxanthin nanoemulsion in the polymer matrix systems, optimization of polymers and plasticizer concentrations were carried out by using Design-Expert ${ }^{\circledR}$ version 12 Software with Simple Lattice Design method. This software is a tool to determine the optimal variations in polymers and plasticizer concentrations in a thin film preparation. Using this software will produce eight experimental designs for each of the natural polymers that were used. Critical evaluations including film disintegration time and film thickness were carried out to find the best thin film characteristics. The results of the evaluation in the preliminary screening of thin film-matrix systems are given in Table 2. All of the formulas had good characteristics of both disintegration 
time and thickness (Table 2). The best characteristic of thin film from both sodium alginate and gelatin were determined by using Simplex Lattice Design modeling. The film thickness and film disintegration time parameters were used to determine the optimum film formulation to be used in the TFANE preparation.
The results of data analysis from the model are presented in Figure 1.

Based on the contour plots in Figure 1, it can be seen that the effects of application of sodium alginate and gelatin in the matrix systems were similar. Although the shape of the

\section{Table 2. The results of preliminary screening on optimization of polymer matrix systems}

\begin{tabular}{|c|c|c|c|c|c|c|c|c|}
\hline Parameters & Formula & & & & & & & \\
\hline \multirow{3}{*}{$\begin{array}{l}\text { Film thickness } \\
(\mathrm{mm})^{\star}\end{array}$} & $\mathrm{F} 1$ & $\mathrm{~F} 2$ & F3 & $\mathrm{F} 4$ & F5 & F6 & $\mathrm{F} 7$ & F8 \\
\hline & $0.137 \pm 0.001$ & $0.159 \pm 0.001$ & $0.182 \pm 0.001$ & $0.192 \pm 0.001$ & $0.203 \pm 0.001$ & $0.178 \pm 0.001$ & $0.131 \pm 0.001$ & $0.205 \pm 0.001$ \\
\hline & $0.132 \pm 0.001$ & $0.135 \pm 0.001$ & $0.171 \pm 0.001$ & $0.152 \pm 0.001$ & $0.199 \pm 0.002$ & $0.145 \pm 0.002$ & $0.197 \pm 0.001$ & $0.144 \pm 0.002$ \\
\hline \multirow{3}{*}{$\begin{array}{l}\text { Film } \\
\text { disintegration } \\
\text { time (s)* }\end{array}$} & $\mathrm{F} 1$ & $\mathrm{~F} 2$ & F3 & $\mathrm{F} 4$ & F5 & F6 & $\mathrm{F} 7$ & F8 \\
\hline & F9 & F10 & $\mathrm{F} 11$ & $\mathrm{~F} 12$ & F13 & F14 & F15 & $\mathrm{F} 16$ \\
\hline & $23.03 \pm 0.015$ & $24.58 \pm 0.021$ & $49.68 \pm 0.030$ & $43.89 \pm 0.035$ & $58.42 \pm 0.020$ & $45.93 \pm 0.025$ & $58.00 \pm 0.010$ & $33.96 \pm 0.020$ \\
\hline
\end{tabular}

*Values are given as the mean \pm standard deviation $(n=3)$

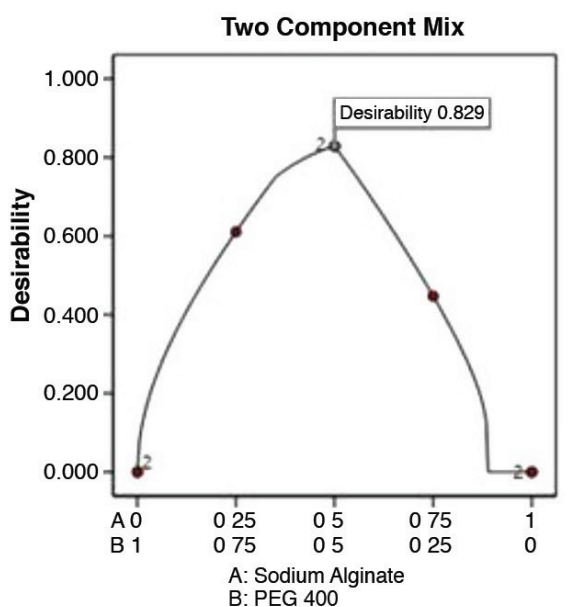

(i)

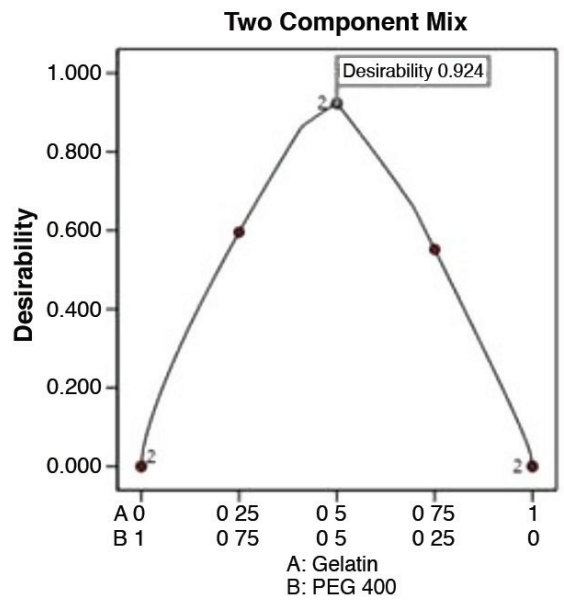

(iv)

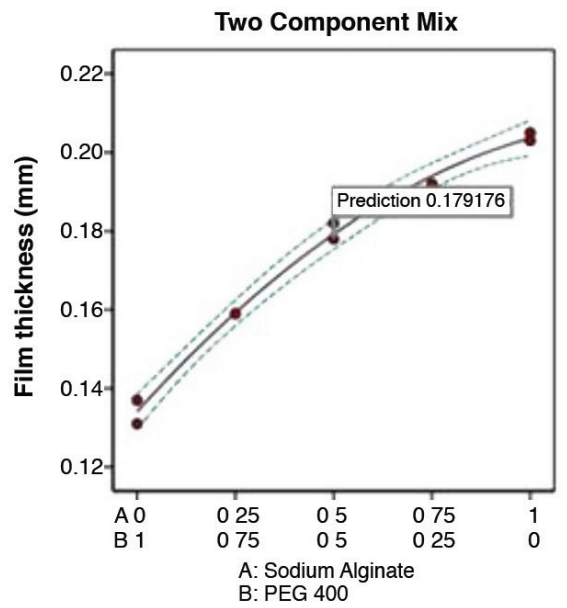

(ii)

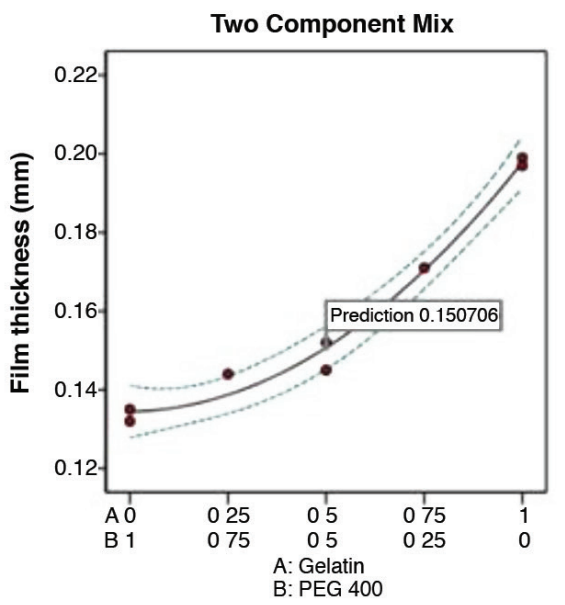

(v)

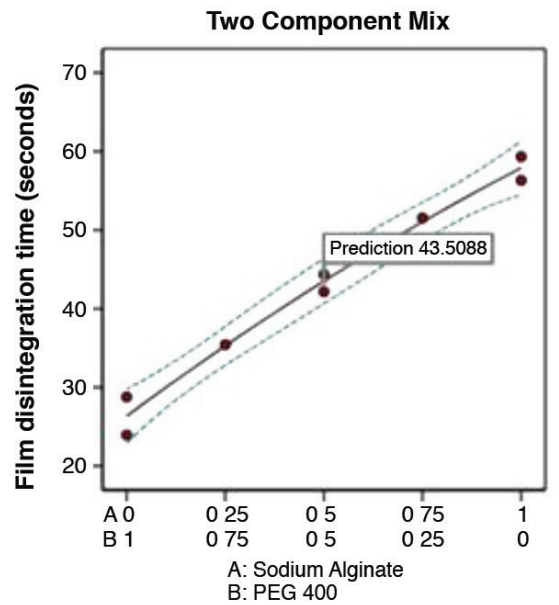

(iii)

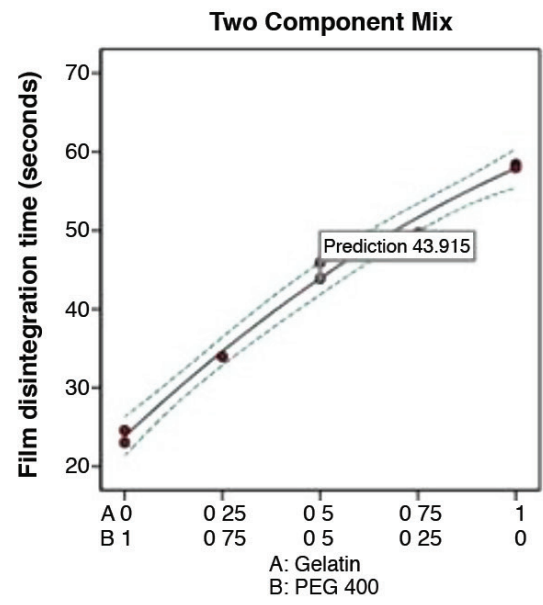

(vi)

Figure 1. Data analysis of thin film optimization using Simplex Lattice Design modeling. (i)-(iii) for sodium alginate and (iv)-(vi) for gelatin PEG: Polyethylene glycol 
contour plot in film thickness was different, sodium alginate has a convex quadratic shape, whereas gelatin had a concave quadratic shape. The higher of the two polymer concentrations, the longer of the film disintegration time needed and the greater the film thickness. In contrast to the effects of PEG on film thickness and disintegration time, with the higher PEG concentration, a thinner film was produced and the film disintegrated faster. The polymer concentration is an important factor in the development of the thin film. The integrity of fast-dissolving oral films is dependent upon the nature of the selected polymer and its concentration. Different polymers are employed to modulate the diverse properties of films. ${ }^{9,10}$ PEG also has good film-forming properties either alone or in combination with other polymers." The disintegration rate of the polymers is decreased by increasing the molecular weight and its concentration of the polymer film matrix system. ${ }^{12,13}$ In thin film development, mechanical properties such as tensile strength and percent elongation are improved by adding a plasticizer to the formulations. ${ }^{12}$ The mechanical properties of a thin film depends on the plasticizer concentration; ${ }^{13}$ thus, proper selection of a plasticizer is very important as improper selection may cause cracking and splitting of the film.2,14

The desirability value in Figure 1 (i) showed the highest value (0.829) in a mixture of sodium alginate and PEG 400 with a film thickness of approximately $0.179176 \mathrm{~mm}$ and a film disintegration time of approximately 43.5088 s, whereas Figure 1 (iv) shows the highest value (0.924) in a mixture of gelatin and PEG 400 with a film thickness of approximately $0.150706 \mathrm{~mm}$ and a film disintegration time of approximately $43.915 \mathrm{~s}$. The desirability value can range from zero (outside of the limits) to one (at the goal). Desirability is simply a mathematical method to determine the optimum (closed to one).15 Thus, it can be concluded that the two best polymer matrix systems for the preparation of TFANE were mixtures containing $1.75 \%(\mathrm{w} / \mathrm{v})$ sodium alginate and 1.5\% (w/v) PEG 400 and those comprising $3 \%(\mathrm{w} / \mathrm{v})$ gelatin and $0.75 \%(\mathrm{w} / \mathrm{v})$ PEG 400.

\section{Preparation of TFANE}

The film properties of astaxanthin nanoemulsions prepared with both sodium alginate and gelatin are presented in Table 3.
In this study, the films prepared using a 10-mm-diameter petri dish showed good weight homogeneity. All films showed a disintegration time of less than $60 \mathrm{~s}$, which related to ease of drug release from the matrix system. The ideal intraoral film should have the following mechanical properties: High tensile strength and high percent elongation. The astaxanthin nanoemulsion incorporated into the gelatin matrix system had a higher tensile strength and higher percent elongation values than the sodium alginate matrix system (Table 3 ). Tensile strength is the maximum stress applied to a point at which the film breaks, whereas percent elongation indicates the ability to stretch when a stress is applied. Hard and brittle films demonstrate high tensile strength, ${ }^{16}$ which means that the film made from sodium alginate was relatively smoother than that made from gelatin. The percent elongation of the gelatin matrix system was greater than that of the sodium alginate matrix system, which means that the film made from gelatin was more flexible than that made from sodium alginate.

Referring to a study conducted by Lakshmi et al. ${ }^{17}$, Eudragit ${ }^{\circledR}$ EPO was selected as the second polymer because the film made from this polymer showed good tensile strength. Other studies have also shown that Eudragit ${ }^{\circledR}$ EPO has taste-masking properties to prevent a negative impact on patient compliance, which is a major consideration when developing an oral formulation. 18,19

Visual observation of the TFANE was conducted by observing its organoleptic properties. The TFANE was orange in color, odorless, with a smooth surface, and transparent (Figure 2). The morphology of the surface film was observed by SEM (Figure 3). Clear differences were observed between the TFANE containing sodium alginate and gelatin matrix systems, in which the film made from sodium alginate showed a grainier texture than that made from gelatin.

At the end of the study, in vitro dissolution tests were performed to compare the drug release profiles of the sodium alginate and gelatin matrix systems. The plotted curves of percentage release over time are shown in Figure 4. The films formed by sodium alginate and gelatin released $>90 \%$ of the drug within 15 minutes. These results indicate that there was no difference

Table 3. Physical and mechanical properties of TFANE

\begin{tabular}{lll}
\multirow{2}{*}{ Parameters } & Polymer matrix systems & \\
\cline { 2 - 3 } & $1.75 \%(w / v)$ sodium alginate $+1.5 \%(w / v)$ PEG 400 & $3 \%(w / v)$ gelatin $+0.75 \%(w / v)$ PEG 400 \\
\hline Visual properties of WME & Orange, clear, and odorless & Orange, clear, and odorless \\
\hline pH of WME* & $6.56 \pm 0.05$ & $6.80 \pm 0.01$ \\
\hline Film thickness $(\mathrm{mm})^{*}$ & $0.196 \pm 0.001$ & $0.184 \pm 0.008$ \\
\hline Weight uniformity/sheet $3 \times 3 \mathrm{~cm}(\mathrm{~g})^{*}$ & $0.221 \pm 0.002$ & $0.202 \pm 0.007$ \\
\hline Film disintegration time $(\mathrm{s})^{*}$ & $48.69 \pm 0.10$ & $47.64 \pm 0.70$ \\
\hline Tensile strength $(\mathrm{MPa})^{*}$ & $2.01 \pm 0.16$ & $5.33 \pm 0.40$ \\
\hline Percent elongation $(\%)^{*}$ & $12.76 \pm 1.17$ & $77.15 \pm 7.29$ \\
\hline Assay of astaxanthin $(\%)^{*}$ & $98.85 \pm 0.54$ & $98.73 \pm 0.47$ \\
\hline
\end{tabular}

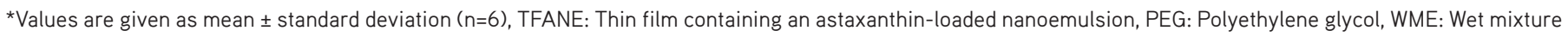




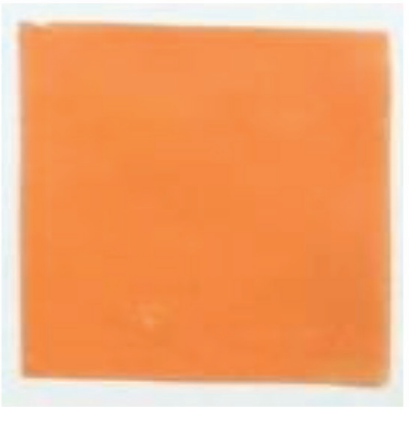

(A)

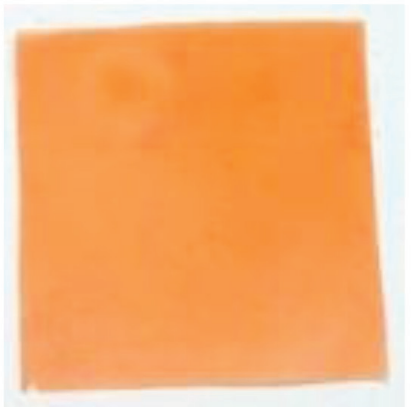

(B)
Figure 2. Visual observation of TFANE. (A) TFANE was contained the sodium alginate matrix system and (B) TFANE was contained the gelatin matrix system

TFANE: Thin film containing an astaxanthin-loaded nanoemulsion

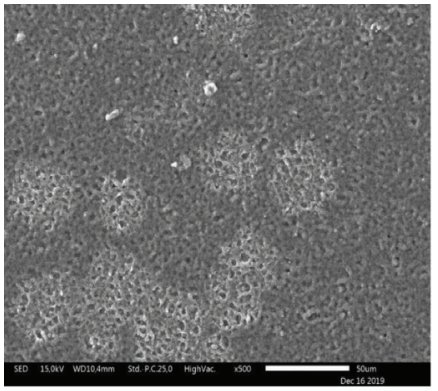

(A)

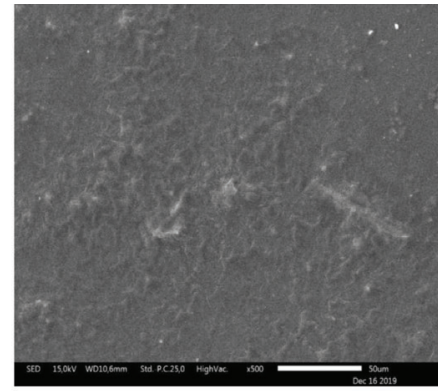

(B)
Figure 3. The morphology of TFANE at 500x magnification. (A) TFANE was contained the sodium alginate matrix system, and (B) TFANE was contained the gelatin matrix system

TFANE: Thin film containing an astaxanthin-loaded nanoemulsion

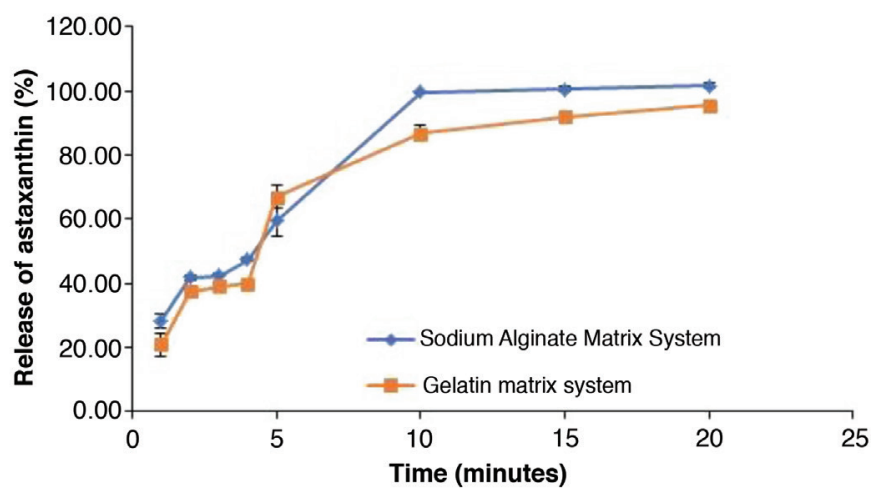

Figure 4. In vitro drug release from TFANE prepared using sodium alginate and gelatin polymers

TFANE: Thin film containing an astaxanthin-loaded nanoemulsion

regarding drug release between films made from sodium alginate and those made from gelatin.

\section{CONCLUSION}

An intraoral film containing an astaxanthin-loaded nanoemulsion with good physical and mechanical properties was successfully developed using a natural polymer matrix system. The film made from a gelatin matrix system containing astaxanthin nanoemulsion was more flexible and harder than film made from a sodium alginate matrix system, whereas all of the films had the characteristics that made them ideal for intraoral delivery. There was no difference regarding drug release from films made by sodium alginate or gelatin. Gelatin as a natural polymer appears to be promising for the preparation of an intraoral thin film delivery system.

\section{ACKNOWLEDGMENTS}

The authors gratefully acknowledge the generous grant from The Indonesian Ministry of Education Directorate General of Higher Education that made this study possible. The authors are also thankful to the Faculty of Pharmacy, Padjadjaran University, for providing the support and their facilities.

Conflicts of interest: No conflict of interest was declared by the authors. The authors alone are responsible for the content and writing of the paper.

\section{REFERENCES}

1. Choi HD, Kang HE, Yang SH, Lee MG, Shin WG. Pharmacokinetics and first-pass metabolism of astaxanthin in rats. Br J Nutr. 2011;105:220227.

2. Ambati RR, Phang SM, Ravi S, Aswathanarayana RG. Astaxanthin: sources, extraction, stability, biological activities and its commercial applications-a review. Mar Drugs. 2014;12:128-152.

3. Affandi MM, Julianto T, Majeed AB. Enhanced oral bioavailability of astaxanthin with droplet size reduction. Food Sci Technol Res. 2012;18:549-554.

4. Krstić M, Medarević $Đ$, Đuriš J, Ibrić S. Self-nanoemulsifying drug delivery systems (SNEDDS) and self-microemulsifying drug delivery systems (SMEDDS) as lipid nanocarriers for improving dissolution rate and bioavailability of poorly soluble drugs. Lipid nanocarriers for drug targeting. Norwich, NY; William Andrew Publishing; 2018:473-508.

5. Date AA, Desai N, Dixit R, Nagarsenker M. Self-nanoemulsifying drug delivery systems: formulation insights, applications and advances. Nanomedicine. 2010;5:1595-1616.

6. Nurdianti L, Aryani R, Indra I. Formulasi dan karakterisasi SNE (Self Nanoemulsion) astaxanthin dari Haematococcus pluvialis sebagai super antioksidan alami. J Sains Farm Klin. 2017;4:36-42.

7. Bala R, Pawar P, Khanna S, Arora S. Orally dissolving strips: A new approach to oral drug delivery system. Int J Pharm Investig. 2013;3:67.

8. Sharma R, Parikh RK, Gohel MC, Soniwala MM. Development of taste masked film of valdecoxib for oral use. Indian J Pharm Sci. 2007;69:320.

9. Irfan M, Rabel S, Bukhtar Q, Qadir MI, Jabeen F, Khan A. Orally disintegrating films: A modern expansion in drug delivery system. Saudi Pharm J. 2016;24:537-546.

10. Karki S, Kim H, Na SJ, Shin D, Jo K, Lee J. Thin films as an emerging platform for drug delivery. Asian J Pharm Sci. 2016;11:559-574.

11. Pathare YS, Hastak VS, Bajaj AN. Polymers used for fast disintegrating oral films: a review. Polymer. 2013;14:169-178.

12. Joshua JM, Hari R, Jyothish FK, Surendran SA. Fast dissolving oral thin films: An effective dosage form for quick releases. Drugs. 2016;11:12. 
13. Siddiqui MN, Garg G, Sharma PK. A short review on "A novel approach in oral fast dissolving drug delivery system and their patents". Adv Biol Res. 2011;5:291-303.

14. Mandeep K, Rana AC, Nimrata S. Fast dissolving films: an innovative drug delivery system. Int J Pharm Res Allied Sci. 2013;2:14-24.

15. Anderson MJ, Whitcomb PJ. Optimizing formulation performance with desirability functions. InQuebec Metallurgical Conference; 1993.

16. Dixit RP, Puthli SP. Oral strip technology: overview and future potential. J Control Release. 2009;139:94-107.

17. Lakshmi PK, Sreekanth J, Sridharan A. Formulation development of fast releasing oral thin films of levocetirizine dihydrochloride with Eudragit ${ }^{\circledR}$
EPO and optimization through Taguchi orthogonal experimental design. Asian J Pharm. 2014;5:84-92.

18. Kayumba PC, Huyghebaert N, Cordella C, Ntawukuliryayo JD, Vervaet C, Remon JP. Quinine sulphate pellets for flexible pediatric drug dosing: formulation development and evaluation of taste-masking efficiency using the electronic tongue. Eur J Pharm Biopharm. 2007;66:460-465.

19. Wieland-Berghausen S, Schote U, Frey M, Schmidt F. Comparison of microencapsulation techniques for the water-soluble drugs nitenpyram and clomipramine $\mathrm{HCl}$. J Control Release. 2002;85:35-43. 